\title{
Editors' Notes
}

\section{CONFERENCE}

The Centre of Asian Studies of the University of Hong Kong and the American Studies Association of Hong Kong are planning to hold an international conference on all aspects-cultural, intellectual, diplomatic, economic, and technological-of SinoAmerican relations since 1900. Proposals for papers or complete panels in this area are welcome. The conference organizers particularly encourage papers which utilize Chinese-language sources. Please send one-page summary and brief vita by 31 October 1988 to: Dr. Priscilla Roberts, History Department, University of Hong Kong, Pokfulam Road, Hong Kong.

\section{COMPETITION FOR RECENTLY COMPLETED DOCTORAL THESES}

Young scholars are invited to present summaries of their doctoral research at the Leuven Congress of the International Economic History Association in August 1990. Summaries of the theses (no more than 3,000 words) will be published in a volume of the congress proceedings, and four prizes of $\$ 1,000$ will be awarded.

Candidates must have been awarded their doctorate or equivalent after September 1, 1984 and must have been less than 40 years of age at the time the degree was awarded. Applications should include three copies of both the summary and an additional statement of under 2,000 words regarding sources and bibliography. Do not send the thesis itself.

The deadline for submissions is February 1, 1989. For details, write Professor Joseph Goy, General Secretary, International Economic History Association, Ecole des Hautes Etudes en Sciences Sociales, Centre de Recherches Historiques, 54, Boulevard Raspail, 75270 Paris, France. The letter of inquiry should include the thesis title, the names of supervisor and readers, the institution which awarded the degree, and the date of successful completion of degree requirements.

\section{FELLOWSHIPS AND GRANTS}

The Columbia University Society of Fellows in the Humanities will appoint a number of postdoctoral fellows in the humanities for the academic year 1989/90, with expectation of renewal for a second year. Fellows must have received the Ph.D. between January 1, 1986 and July 1, 1989. The stipend will be $\$ 28,500$, one-half for independent research and one-half for teaching in the undergraduate program in general education. Additional funds are available to support research. Deadline for completed applications is October 15, 1988. For application forms write: Director, Society of Fellows in the Humanities, Heyman Center for the Humanities, Box 100 Central Mail Room, Columbia University, New York, NY 10027.

The Committee on Scholarly Communication with the People's Republic of China offers the following program of scholarly exchanges with China.

The Visiting Scholar Exchange Program supports one-to-three-month visits for American and Chinese scholars in all disciplines between September 1989 and August 1990. For Americans in social sciences and humanities, the program supports scholars outside the China studies field to initiate and conduct research. The program also supports the nomination of Chinese scholars by American scholars, priority being given to Chinese who have not visited the United States recently. Deadline for application to the Visiting Scholar Exchange Program is November 15, 1988.

The Graduate Program supports individuals enrolled in a graduate program in social sciences or humanities to do coursework or dissertation research at a Chinese 
university. The Research Program supports postdoctoral research in the social sciences and humanities. Recipients of research grants normally spend from two months to one year in the PRC, beginning July 1989 and ending December 1990. Deadline for application to the Graduate or the Research Program is October 15, 1988.

For application information write: Committee on Scholarly Communication with the People's Republic of China, National Academy of Sciences, 2101 Constitution Avenue, Washington, DC 20418.

The Walter P. Reuther Archives of Labor and Urban Affairs at Wayne State University, Detroit, is offering awards of up to $\$ 700$ to cover travel and expenses related to research at the Archives. The grants are intended primarily for graduate students working on their dissertations and junior faculty pursuing research projects. For information and application forms contact: Philip P. Mason, Director, Archives of Labor and Urban Affairs, Walter P. Reuther Library, Wayne State University, Detroit, MI 48202; telephone (313) 577-4024.

The National Humanities Center offers 35 to 40 fellowships for postdoctoral or equivalent-level work in history, philosophy, languages and literature, classics, religion, history of the arts, and other fields in the liberal arts. Social scientists or professionals whose work has a humanistic dimension are welcome to apply. Fellows are required to work at the Center, where they have private studies, library and manuscript typing services, and other administrative support. The fellowships, usually for the academic year September through May, seek to maintain scholars at their usual income, though they cannot in every instance replace full salaries. Scholars with partial support, in the form of sabbatical salaries or grants from other sources, may request from the Center the difference between that support and their normal salaries. The Center also provides round-trip travel expenses for Fellows and their immediate families. Application deadline is October 15, 1988. For application material write: Kent Mullikin, Assistant Director, National Humanities Center, 7 Alexander Drive, P.O. Box 12256, Research Triangle Park, NC 27709-2256.

\section{U.S. COUNTY BOUNDARY FILES}

A boundary file of U.S. counties for the census decades 1850 through 1970 is now available in either Atlas AMP or Atlas Graphics format for use on IBM-compatible PCs with hard disks. The complete file of 13 census years is contained on $514^{\prime \prime}$ diskettes. AT or AT-compatible users should order the file on high-density disks, which sell for $\$ 350$; other users should order the file on low-density disks, which sell for $\$ 400$. Files for individual census years are available for $\$ 50$ per year. Orders should specify format (Atlas AMP or Atlas Graphics) and disk density. Checks should be payable to the Department of Geography, Miami University, Oxford, OH 45056. For information call Cyrus Young or Carville Earle, telephone (513) 529-5010.

\section{RECORDS AVAILABLE ON MICROFILM}

University Publications of America (44 North Market Street, Frederick, MD 21701; telephone (800) 692-6300) has a number of records available on microfilm that may be of interest to economic historians.

The CIO Files of John L. Lewis is divided into two parts. Part I: Correspondence with CIO Unions, 1929-1962 (25 reels) contains Lewis's exchanges with all of the international unions that made up the CIO. Part II: General Files, 1937-1955 (20 reels) contains several series of records pertaining to the internal administration and operation of the union, as well as Lewis's files on UMWA-CIO-AFL relations.

Department of Justice Investigative Files: The Industrial Workers of the World (15 
reels) provides the official Justice Department documentation on the federal government's campaign against the IWW.

Records of the Women's Bureau of the U.S. Department of Labor, 1918-1965. Part I: Reports of the Director, Annual Summaries, Major Conferences, Speeches, and Articles (23 reels) portrays the evolution both of the American woman at work and the governmental agency mandated by federal law "to investigate and improve the conditions of women workers."

Thomas A. Edison Papers. Part I: 1850-1878 (28 reels) and Part II: 1879-1896 69 reels).

The Salmon P. Chase Papers (43 reels) cover the period 1849 to 1873 , including when Chase was U.S. senator, governor of Ohio, Secretary of the Treasury during the Civil War, and Chief Justice of the United States.

Also available: The Records of the Federal Trade Commission, the Papers of the Federal Reserve System, the James J. Hill Papers, and the Papers of the Great Northern Railway Co. and the Northern Pacific Railway Co.

\section{ANNOTATED BIBLIOGRAPHIES AVAILABLE}

Three bibliographical volumes, edited by Dirk Hoerder and Christiane Harzig, regarding migrants from Europe to America are available from Greenwood Press, Inc., 88 Post Road West, Box 5007, Westport CT 06881. These carry the general title The Immigrant Labor Press in North America, 1840s-1970s. The first volume covers Migrants from Northern Europe; the second, Migrants from Eastern and Southeastern Europe; and the third, Migrants from Southern and Western Europe.

\section{NATIONAL ENDOWMENT FOR THE HUMANITIES REPORT}

Copies of the National Endowment for the Humanities 22nd Annual Report are now available upon request as long as the supply lasts. The Report contains brief descriptions of Endowment programs as well as a complete listing of all Endowment grants, entered by the division and program in which they were funded, for fiscal year 1987 (October 1, 1986 through September 30, 1987). Single copy requests should be sent to NEH 1987 Annual Report, Room 406, 1100 Pennsylvania Avenue NW, Washington, DC 20506.

\section{CALL FOR PAPERS}

The 35th annual meeting of the Business History Conference will be held March 31-April 2, 1989, in Boston. The general theme of the meeting will be "Manufacturing and Marketing." Papers may focus on one of these topics, the two together, or especially on relationships between the two in the development of "new" (at the time) products. Papers, or sessions composed of several papers, on other topics related to business history concerning any country or combination of countries will be welcomed as well. Proposals should be in the form of a one-page precis for each paper, accompanied by a curriculum vitae for intended participants, including commentators. Proposals should be submitted as soon as possible but no later than October 30, 1988, to Professor Thomas K. McCraw, Baker Library 217, Soldiers Field, Boston, MA 02163.

Graduate students who have completed dissertations in business history within the last three calendar years (1986-1988) are encouraged to submit proposals for the dissertation session. A one-page abstract and curriculum vitae should be submitted by the deadline above to Professor Naomi R. Lamoreaux, Department of History, Brown University, Providence, RI 02912. 